\title{
Qūaality of Life and Some Related Factors of Elderly People in Turkmen County,
}

Iran

\section{Shahnaz Moalemi ${ }^{1}$, Maryam Eri*1 ${ }^{*}$, Amene Sadat Sheykholeslami ${ }^{2}$, Arezoo Sadegh Ghelichi ${ }^{3}$, Abbas \\ Malvandi $^{4}$}

1. Health Management and Social Development Research Center, Golestan University of Medical Sciences, Gorgan, Iran

2. Faculty of Medicine, Golestan University of Medical Sciences, Gorgan, Iran

3. Turkmen Healthcare Network, Health Deputy, Golestan University of Medical Sciences, Gorgan, Iran

4. Health Deputy, Golestan University of Medical Sciences, Gorgan, Iran

\begin{abstract}
Background and objectives: Aging and its consequences are one of the major demographic issues in the world. The aim of this study was to determine quality of life and some related factors in elderly people living in Turkmen County (Iran) in 2017.

Methods: This cross-sectional, descriptive-analytic study was conducted on 300 elderly people aged 60 years and older who were living in the Turkmen County, Iran. The subjects were selected via stratified random sampling. Data were collected using the World Health Organization Quality of Life-BREF Questionnaire. Data analysis was performed in SPSS software (version 16) using independent t-test, one-way ANOVA and nonparametric tests, such as Mann-Whitney $U$ test and Kruskal-Wallis test. P-values less than 0.05 were considered statistically significant.

Results: Of 300 subjects, 152 cases $(50.7 \%)$ were women and 148 (49.3\%) were men. The mean total score of quality of life was $54.4 \pm 12.7$. The mean standardized score of quality of life differed significantly depending on marital status, income level and number of children $(\mathrm{P}<0.05)$. There was a significant relationship between the mean standardized score of quality of life in terms of physical health and occupation status, age, income level and number of children. In addition, the mean standardized score of quality of life in the social relationship domain differed significantly based on gender, marital status, income level and number of children. Moreover, the mean standardized score of quality of life in the environmental health domain differed significantly based on occupational status and income level $(\mathrm{P}<0.05)$.

Conclusion: Considering the impact of various factors on quality of life of the elderly, it is crucial to take measures for promoting quality of life in elderly women, unemployed elderly, people aged 80 years or older and those with a low income level.
\end{abstract}

Keywords: Quality of Life; Turkmen; Elderly; Iran

\section{Received: 2019/09/25 $\quad$ Revised:2019/10/05 Published:2019/10/17}

*Correspondence: Maryam Eri, Health Management and Social Development Research Center, $1^{\text {st }}$ Golbarg, Golha alley, Gorgan, Iran

Tel: +98-1732160330

Email: maryameeri@yahoo.com 


\section{INTRODUCTION}

According to the World Health Organization (WHO), old age is defined as a chronological age of 60 years old or older (1). Aging is accompanied by weakening of functional properties at the cell, tissue and organ level (2), which changes the structure and function of different body organs. Elderly people are at increased risk of developing chronic illnesses due to lack of social support an physical/mental disabilities, which limit their activities in the community and reduce their quality of life $(3,4)$. According to the WHO, quality of life is defined as "the individual's perception of their position in life in the context of the culture and value systems in which they live and in relation to their goals" (5). Objective dimensions of quality of life include health status, knowledge, life expectancy, assets, physical and intellectual energy, social communications, etc., while subjective dimensions of quality of life are life satisfaction, happiness and self-esteem (6). Consideration of the underlying factors affecting the quality of life of the elderly plays a significance role in improving their quality of life (7). In a study by Vahdaninia et al., health-related quality of life of the elderly people living in Tehran (Iran) was associated with demographic variables such as age, education level, marital status and occupation (8). In a study in Brazil, university education was significantly correlated with quality of life, and women had a lower quality of life than men (9).

Considering the growth in the share of the elderly population in Iran and the lack of studies on the quality of life of Iranian elderly living in northern provinces of Iran, we aimed to determine the quality of life and some related factors in the elderly living in Turkmen County, northeastern Iran.

\section{MATERIALS AND METHODS}

This descriptive cross-sectional study was carried out in 2017 on 300 elderly people (152 women and 148 men) over 60 years of age who were living in Turkmen County, Golestan Province, north of Iran. All study procedures were performed in accordance with the Declaration of Helsinki. Written consent was also obtained from all participants.

Inclusion criteria were age of 60 years or older, residence in Turkmen County, having Iranian nationality and willingness to participate in the study. Exclusion criteria included severely disabling disorders such as neurological disorders (Stroke, Parkinson), hearing loss, severe mental illness and an abbreviated mental test score of 8 and higher. Sample size was determined based on the Cochran formula and a study by Farhadi et al. (11). 
Journal of Clinical and Basic Research (JCBR). 2019; 3(3): P 25-32.

Table 1. Geographic distribution of subjects in the Turkmen County, Iran

\begin{tabular}{|c|c|c|}
\hline Centers & Number of people over 60 years & Number of participants in the study \\
\hline Health Center No. 1 & 1220 & 65 \\
\hline Center No. 2 & 681 & 36 \\
\hline Urban Health Base No. 1 & 612 & 33 \\
\hline Urban Health Base No. 2 & 1327 & 40 \\
\hline Si Joval & 760 & 15 \\
\hline Panj peykar & 286 & 23 \\
\hline Khajelar & 430 & 6 \\
\hline Neyazabad-Gharesoo & 118 & 11 \\
\hline Chapakly & 202 & 300 \\
\hline Total & 5636 & \\
\hline
\end{tabular}

Table 1 shows the geographical distribution of subjects in the study area. Study subjects were randomly selected according to the population of catchment area and records of the elderly registered in health centers. Given that our study subjects were elderly and may have difficulty reading/writing, the questionnaire was completed with the help of a Turkmen colleague who was fluent in Turkmen and Persian. The questionnaire was completed through face-to-face interviews.

In order to assess the cognitive function of the elderly, we used the Persian version of the AMT, one of the most widely used methods for screening the cognitive status of the elderly (12). The questionnaire has 10 questions and each question correctly answered scores one point. Subjects with a score of 8 and higher were enrolled in the study.

Data were gathered using a two-part questionnaire. The first part included background and demographic information, while the second part consisted of the WHO Quality of Life Questionnaire (WHOQOLBREF) for assessing the quality of life of elderly people. In addition to assessing health- related quality of life, the questionnaire also assesses other aspects of quality of life such as environment, security and financial status of individuals (13). Reliability and validity of this questionnaire were confirmed in a previous study (14). This questionnaire contains 26 questions, 4 subscales and a general score. Subscales include physical health (7 items), mental health (6 items), social relationships (3 items) and environmental health ( 8 items). The first two questions do not belong to any of the domains and assess the health status and quality of life in general. Each domain is scored from 4 to 20 , which can be converted into points with a range of 100. Initially, a raw score is obtained for each subsection, which must be converted to a standard score of $0-100$ through a formula. A higher score indicates a better quality of life. Validity and reliability of the instrument have been confirmed in a study by Nejat et al.(14).

Collected data were analyzed in SPSS software using descriptive and analytical statistics. Results were analyzed using independent t-test, one-way ANOVA and Scheffe's test. In addition, the Mann-Whitney 
Journal of Clinical and Basic Research (JCBR). 2019; 3(3): P 25-32.

and Kruskal-Wallis tests were used for comparison of non-normally distributed data. All statistical analyses were performed at significance level of 0.05 .

\section{RESULTS}

Illiteracy was more common among women (84.1\%). The number of married men $(n=142)$ was higher than that of women $(n=115)$. Also, the number of widowed women $(n=37)$ was higher than that of widowed men $(n=5)$. The mean number of children was $5.9 \pm 2.5$. Moreover, $41.7 \%$ of women and $29.2 \%$ of men had income of less than 5 million Rials (Iranian currency).

Table 2. Demographic characteristics of the subjects

\begin{tabular}{|c|c|c|}
\hline Variable & Frequency & Percent \\
\hline Gender & & \\
\hline Female & 152 & 50.7 \\
\hline Male & 148 & 49.3 \\
\hline Age (years) & & \\
\hline $60-69$ & 184 & 61.3 \\
\hline $70-79$ & 89 & 29.7 \\
\hline 80 and more & 27 & 9.0 \\
\hline Educational level & & \\
\hline Illiterate & 174 & 58.2 \\
\hline Under high school diploma & 65 & 21.7 \\
\hline High school diploma & 37 & 12.4 \\
\hline University degree & 23 & 7.7 \\
\hline Marital status & & \\
\hline Married & 257 & 86.0 \\
\hline Single/widowed & 42 & 14.0 \\
\hline Occupational status & & \\
\hline Unemployed & 166 & 55.3 \\
\hline Employed & 134 & 44.7 \\
\hline Income level (Rials) & & \\
\hline Less than 5 million & 51 & 33.1 \\
\hline 5 to 10 million & 62 & 40.3 \\
\hline 10 to 15 million & 22 & 14.3 \\
\hline More than 15 million & 19 & 12.3 \\
\hline Number of children & & \\
\hline$\leq 3$ & 50 & 17.3 \\
\hline 4 or 5 & 79 & 27.3 \\
\hline$\geq 6$ & 160 & 55.4 \\
\hline
\end{tabular}

Table 2 shows the demographic characteristics of the subjects. The mean standardized score of quality of life was $\mathbf{5 4 . 4 5}$

\pm 12.74 . The mean standardized score of quality of life in each dimension is shown in table 3 .

Table 3. Mean score of quality of life in different domains

\begin{tabular}{|c|c|c|c|}
\hline Domain & Mean \pm Standard deviation & Minimum & Maximum \\
\hline Physical health & $52.6 \pm 12.5$ & 17.9 & 85.7 \\
\hline Mental health & $50.0 \pm 14.6$ & 0 & 100 \\
\hline Social relationship & $57.4 \pm 20.6$ & 8.3 & 100 \\
\hline Environmental health & $56.7 \pm 16.9$ & 3.1 & 100 \\
\hline Overall quality of life & $54.4 \pm 12.7$ & 14.4 & 90.4 \\
\hline
\end{tabular}


Journal of Clinical and Basic Research (JCBR). 2019; 3(3): P 25-32.

The results also showed that the mean standardized score of quality of life was significantly associated with marital status,

Table 4. Factors related to the quality of life of the elderly living in the Turkmen County, Iran

\begin{tabular}{|c|c|c|c|c|c|c|}
\hline \multicolumn{2}{|l|}{ Variables } & Physical health & $\begin{array}{l}\text { Mental } \\
\text { health }\end{array}$ & $\begin{array}{c}\text { Social } \\
\text { relationship }\end{array}$ & $\begin{array}{c}\text { Environmental } \\
\text { health }\end{array}$ & $\begin{array}{c}\text { Overall quality of } \\
\text { life }\end{array}$ \\
\hline & & Mean \pm SD & Mean $\pm \mathrm{SD}$ & Mean $\pm \mathrm{SD}$ & Mean $\pm \mathrm{SD}$ & Mean $\pm \mathrm{SD}$ \\
\hline \multirow{3}{*}{ Gender } & Female & $52.3 \pm 12.7$ & $49.2 \pm 14.8$ & $54.7 \pm 21.6$ & $55.4 \pm 17.2$ & $53.4 \pm 13.0$ \\
\hline & Male & $52.9 \pm 12.4$ & $50.9 \pm 14.5$ & $60.2 \pm 19.1$ & $58.1 \pm 16.7$ & $55.5 \pm 12.4$ \\
\hline & $\begin{array}{c}\text { Test statistics } \\
\text { P-value }\end{array}$ & $\begin{array}{c}\mathrm{t}=0.409, \mathrm{df}=298 \\
0.68\end{array}$ & $\begin{array}{c}\mathrm{z}=-0.813 \\
0.42\end{array}$ & $\begin{array}{c}\mathrm{z}=-2.144 \\
0.03\end{array}$ & $\begin{array}{c}\mathrm{z}=-1.287 \\
0.19\end{array}$ & $\begin{array}{c}\mathrm{t}=1.438, \mathrm{df}=298 \\
0.23\end{array}$ \\
\hline \multirow{3}{*}{ Marital status } & Married & $52.9 \pm 12.6$ & $50.7 \pm 14.7$ & $59.9 \pm 19.6$ & $56.8 \pm 17.2$ & $55.0 \pm 12.8$ \\
\hline & Widowed & $50.7 \pm 11.8$ & $45.9 \pm 13.6$ & $42.3 \pm 20.3$ & $55.8 \pm 15.7$ & $50.9 \pm 11.5$ \\
\hline & $\begin{array}{c}\text { Test statistics } \\
\text { P-value }\end{array}$ & $\begin{array}{c}\mathrm{z}=-1.009 \\
0.31\end{array}$ & $\begin{array}{c}\mathrm{z}=-1.51 \\
0.13\end{array}$ & $\begin{array}{c}\mathrm{z}=-5.106 \\
0.000\end{array}$ & $\begin{array}{c}\mathrm{z}=-0.01 \\
0.99\end{array}$ & $\begin{array}{c}\mathrm{t}=1.979, \mathrm{df}=297 \\
0.04\end{array}$ \\
\hline \multirow{5}{*}{$\begin{array}{l}\text { Educational } \\
\text { level }\end{array}$} & Illiterate & $52.1 \pm 12.4$ & $49.3 \pm 14.3$ & $56.3 \pm 20.3$ & $56.5 \pm 16.4$ & $53.9 \pm 12.0$ \\
\hline & $\begin{array}{c}\text { Under high } \\
\text { school diploma }\end{array}$ & $53.5 \pm 13.7$ & $51.5 \pm 16.2$ & $59.3 \pm 20.8$ & $56.4 \pm 19.2$ & $55.0 \pm 14.8$ \\
\hline & $\begin{array}{l}\text { High school } \\
\text { diploma }\end{array}$ & $53.6 \pm 10.8$ & $50.2 \pm 13.2$ & $58.8 \pm 17$ & $57.9 \pm 14.9$ & $55.5 \pm 11.4$ \\
\hline & $\begin{array}{l}\text { University } \\
\text { degree }\end{array}$ & $52.3 \pm 13.1$ & $50.9 \pm 15.2$ & $57.9 \pm 26.8$ & $57.2 \pm 18.4$ & $54.8 \pm 13.9$ \\
\hline & $\begin{array}{c}\text { Test statistics } \\
\text { P-value }\end{array}$ & $\begin{array}{c}\mathrm{X}^{2}=1.192, \mathrm{df}=3 \\
0.75\end{array}$ & $\begin{array}{c}\mathrm{X}^{2}=1.555 \\
\mathrm{df}=3 \\
0.67\end{array}$ & $\begin{array}{c}\mathrm{X}^{2}=0.829, \mathrm{df}= \\
3 \\
0.84\end{array}$ & $\begin{array}{c}\mathrm{F}=0.086, \mathrm{df}=3,295 \\
0.97\end{array}$ & $\begin{array}{c}\mathrm{X}^{2}=1.022, \mathrm{df}=3 \\
0.79\end{array}$ \\
\hline \multirow{3}{*}{$\begin{array}{c}\text { Employment } \\
\text { status }\end{array}$} & unemployed & $51.3 \pm 12.6$ & $48.9 \pm 14.7$ & $56.7 \pm 19.2$ & $55.0 \pm 17.1$ & $53.2 \pm 12.5$ \\
\hline & employed & $54.2 \pm 12.3$ & $51.5 \pm 14.4$ & $58.2 \pm 22.2$ & $58.8 \pm 16.6$ & $56.0 \pm 12.9$ \\
\hline & $\begin{array}{c}\text { Test statistics } \\
\text { P-value }\end{array}$ & $\begin{array}{c}\mathrm{t}=-2.014, \mathrm{df}=298 \\
0.04\end{array}$ & $\begin{array}{c}\mathrm{z}=-1.447 \\
0.15\end{array}$ & $\begin{array}{c}\mathrm{z}=-0.576 \\
0.56\end{array}$ & $\begin{array}{c}\mathrm{t}=-1.941, \mathrm{df}=298 \\
0.05\end{array}$ & $\begin{array}{c}\mathrm{t}=-1.888, \mathrm{df}=298 \\
0.06\end{array}$ \\
\hline \multirow{4}{*}{ Age (years) } & $60-69$ & $53.2 \pm 12.8$ & $50.7 \pm 15.2$ & $57.6 \pm 20.4$ & $54.9 \pm 18.0$ & $54.1 \pm 13.6$ \\
\hline & $70-79$ & $53.2 \pm 11.4$ & $49.5 \pm 14.1$ & $58.4 \pm 21.5$ & $58.8 \pm 15.7$ & $55.3 \pm 11.6$ \\
\hline & 80 and more & $46.8 \pm 13.5$ & $47.7 \pm 12.2$ & $52.8 \pm 18.2$ & $61.8 \pm 11.3$ & $53.3 \pm 10.4$ \\
\hline & $\begin{array}{c}\text { Test statistics } \\
\text { P-value }\end{array}$ & $\begin{array}{c}\mathrm{F}=0.311, \mathrm{df}=2,296 \\
0.04\end{array}$ & $\begin{array}{c}X^{2}=1.554 \\
d f=r \\
0.46\end{array}$ & $\begin{array}{c}\mathrm{X}^{2}=2.377, \mathrm{df}= \\
2 \\
0.30\end{array}$ & $\begin{array}{c}X^{2}=5.358, d f=2 \\
0.06\end{array}$ & $\begin{array}{c}\mathrm{F}=0.311, \mathrm{df}=2,296 \\
0.68\end{array}$ \\
\hline \multirow{5}{*}{$\begin{array}{l}\text { Income level } \\
\text { (Rials) }\end{array}$} & $\begin{array}{c}\text { Less than } 5 \\
\text { million }\end{array}$ & $55.4 \pm 9.4$ & $51.3 \pm 14.6$ & $63.6 \pm 20.6$ & $59 \pm 14.9$ & $57.1 \pm 10.9$ \\
\hline & 5 to 10 million & $50.9 \pm 12.3$ & $48.4 \pm 12.1$ & $48.8 \pm 17.2$ & $53.4 \pm 13.9$ & $51.3 \pm 10.3$ \\
\hline & 10 to 15 million & $57.8 \pm 12.9$ & $54.5 \pm 12.3$ & $67.0 \pm 23.2$ & $63.3 \pm 17.2$ & $60.4 \pm 12.5$ \\
\hline & $\begin{array}{c}\text { More than } 15 \\
\text { million }\end{array}$ & $53.4 \pm 7.7$ & $50.4 \pm 16.2$ & $52.6 \pm 20.6$ & $57.1 \pm 15.5$ & $54.0 \pm 11.5$ \\
\hline & $\begin{array}{c}\text { Test statistics } \\
\text { P-value }\end{array}$ & $\begin{array}{c}\mathrm{F}=2.777, \mathrm{df}=3,150 \\
0.04\end{array}$ & $\begin{array}{c}\mathrm{X}^{2}=4.266 \\
\mathrm{df}=3 \\
0.23\end{array}$ & $\begin{array}{c}\mathrm{X}^{2}=20.697 \\
\mathrm{df}=3 \\
<0.001\end{array}$ & $\begin{array}{c}\mathrm{F}=2.806, \mathrm{df}=3,150 \\
0.04\end{array}$ & $\begin{array}{c}\mathrm{X}^{2}=14.866, \mathrm{df}=3 \\
0.002\end{array}$ \\
\hline \multirow{4}{*}{$\begin{array}{l}\text { Number of } \\
\text { children }\end{array}$} & $\leq 3$ & $56.3 \pm 10.3$ & $49.2 \pm 16.2$ & $66.8 \pm 17.0$ & $60.6 \pm 13.2$ & $57.9 \pm 8.8$ \\
\hline & 4 or 5 & $52.9 \pm 11.8$ & $51.0 \pm 14.7$ & $55.9 \pm 21.7$ & $55.4 \pm 15.4$ & $54.1 \pm 12.5$ \\
\hline & $\geq 6$ & $51.2 \pm 13.6$ & $49.5 \pm 15.5$ & $54.9 \pm 20.3$ & $56.0 \pm 18.3$ & $53.3 \pm 13.8$ \\
\hline & $\begin{array}{c}\text { Test statistics } \\
\text { P-value }\end{array}$ & $\begin{array}{c}\mathrm{F}=3.214, \mathrm{df}=2,286 \\
0.04\end{array}$ & $\begin{array}{c}X^{2}=0.718, \\
d f=r \\
0.69\end{array}$ & $\begin{array}{c}X^{2}=14.803, \\
d f=r \\
0.001\end{array}$ & $\begin{array}{c}\mathrm{X}^{2}=3.466, \mathrm{df}=2 \\
0.17\end{array}$ & $\begin{array}{c}\mathrm{X}^{2}=7.675, \mathrm{df}=2 \\
0.02\end{array}$ \\
\hline
\end{tabular}

According to results of one-way ANOVA and Kruskal-Wallis tests, there was no significant relationship between the mean standardized income level and number of children (Table 4). score of quality of life and level of education $(\mathrm{P}>0.05)$. 
The Mann-Whitney test indicated a significant relationship between the domain of social relationships and gender $(\mathrm{P}=0.032)$ in a way that men had a higher mean score of social relationships compared with women (Table 4).

Based on the results of one-way ANOVA test, there was a significant relationship between the mean standardized score of quality of life in the physical health domain in different age groups $(\mathrm{P}=0.043)$.

There was a significant relationship between social relationships and marital status $(\mathrm{P}<0.001)$; married elderly had a higher mean score of social relationships compared with widowed/divorced single elderly. Moreover, there was a significant relationship between physical health and occupation status $(\mathrm{P}=0.045)$. The number of children had a significant negative association with physical health and social relationship (Table 4).

\section{DISCUSSION}

The mean total score of quality of life among elderly people in Turkmen County was less than that of two previous studies in Iran (10, 15). We found no significant relationship between quality of life and gender. This finding is in line with results of a study in Tabriz (15) and Zahedan (16). However, two previous studies in Tehran (17) and in

Marivan (18) reported that quality of life was significantly higher in men.

The results of this study showed that the quality of life of elderly men in the social relationships domain was more than that of elderly women, which could be due to the cultural norms and the different role of men and women in family as well as society.

In this study, the quality of life of married elderly was significantly higher than that of widowed elderly. This finding is consistent with results of a study by Ahangari et al. (17). In general, elderly widows have a lower physical and mental quality of life than their married counterparts $(19,20)$. Also, the mean scores of quality of life in terms of social relations were higher in married elderly compared with elderly widows. This is probably due to the fact that married elderly people have a higher level of social activity and social relations than single elderly people (21).

The quality of life in the area of physical health was significantly higher in subjects aged 60-69 years compared to those aged above 80 years. At older ages, physical activity decreases due to reduced muscle strength, changes in body fat, flexibility, agility and endurance (22).

We found that the income level had a significant effect on variables of quality of life including environmental health, physical health and social relationships. However, previous studies have not reported such relationship between income level and quality of life of elderly people.

Employed subjects had a higher quality of physical health compared to unemployed subjects. Indeed, unemployment is accompanied with negative health-related outcomes and long-term stress, ultimately resulting in a decreased quality of life (23).

We found no significant relationship between quality of life and education level among the subjects. This finding is inconsistent with findings of a study in Brazil (24) that assessed the quality of life of Brazilian elderly using the WHOQOL-BREF questionnaire. However, this difference may be because of differences in the study population and research environment.

Comparison of our findings to previous studies was limited by the lack of studies on the elderly Turkmen and the cultural, economic and social differences of this ethnic group compared to the rest of the Iran's population. However, as oppose to previous studies, the present study included a large population of elderly that was not limited to nursing homes.

\section{CONCLUSION}

According to the findings of the study, the quality of life of the elderly over 60 years of age in the Turkmen County is moderate. Considering the increase in the population of Iranians aged 60 years and older in Northern provinces of Iran, effective planning to 
Journal of Clinical and Basic Research (JCBR). 2019; 3(3): P 25-32.

improve the quality of life of the elderly and attention to their needs are necessary.

\section{ACKNOWLEDGEMENTS}

The authors wish to thank all participants for their cooperation.

\section{DECLARATIONS \\ Funding}

This study was financially supported by the Golestan University of Medical Sciences, Iran.

\section{Ethics approvals and consent to participate}

This study was approved by the Ethics Committee of Golestan University of Medical Sciences (code: IR.Goums.REC.1395. 173).

\section{Conflict of interest}

The authors declare that there is no conflict of interest.

\section{REFERENCES}

1. Maghsoudi E, Pak MHM, Zareei F, Rashid SP, Sofiyani A, Shahidi L. The effect of care plan application based on Roy adaptation model on the self-efficacy in elderly people in urmia nursing homes. Research Journal of Pharmaceutical, Biological and Chemical Sciences. 2015; 6(1):793-9.

2. Fedarko NS. The biology of aging and frailty. Clinics in geriatric medicine. 2011; 27(1):27-37. [DOI:10.1016/j.cger.2010.08.006]

3. Canbaz S, Sunter AT, Dabak S, Peksen Y. The prevalence of chronic diseases and quality of life in elderly people in Samsun. Turkish Journal of Medical Sciences. 2003; 33(5):335-40.

4. Organization WH. Active ageing: A policy framework. Geneva: World Health Organization, 2002.

5. Group W. The World Health Organization quality of life assessment (WHOQOL): position paper from the World Health Organization. Social science \& medicine. 1995; 41(10):1403-9. [DOI:10.1016/0277-9536(95)00112-K]

6. Blane D, Netuveli G. Quality of life in older ages. British Medical Bulletin. 2008; 85(1):11326. [DOI:10.1093/bmb/ldn003]

7. Heravi KM, Rejeh N, Montazeri A. Healthrelated quality of life among abused and nonabused elderly people: a comparative study. PAYESH 2013; 12(5):479-88. [In Persian]
8. Vahdaninia Maryam Sadat GA, Montazeri Ali, Maftoon Farzaneh. Health-related quality of life in the elderly: A demographic study. PAYESH. 2005; 4(2):113-20. [In Persian]

9. Colet CdF, Mayorga P, Amador TA. Educational level, socio-economic status and relationship with quality of life in elderly residents of the city of Porto Alegre/RS, Brazil. Brazilian Journal of Pharmaceutical Sciences. 2010; 46(4):805-10. [DOI:10.1590/S198482502010000400023]

10. Cheraghi Z, Doosti-Irani A, Nedjat S, Cheraghi P, Nedjat S. Quality of life in elderly Iranian population using the QOL-brief questionnaire: A systematic review. Iranian journal of public health. 2016; 45(8):978. [DOI:10.4103/ijpvm.IJPVM_265_16]

11. Farhadi A, Foroughan M, Mohammadi F. The Quality of Life among Rural Elderlies A Crosssectional Study. Iranian Journal of Ageing. 2011; 6(2). [In Persian]

12. Bakhtiyari F, Foroughan M, Fakhrzadeh H, Nazari N, Najafi B, Alizadeh M, et al. Validation Of The Persian Version Of Abbreviated Mental Test (Amt) In Elderly Residents Of Kahrizak Charity Foundation. Iranian Journal of Diabetes and Lipid Disorders. 2014; 13(6):487-94. [In Persian]

13. Yavari P (editor). Epidemiology textbook of prevalent diseases in Iran. Volume 2 Noncommunicable diseases. 2th edn. Tehran: Gap publisher. 2014. [In Persian]

14. Nejat S, Montazeri A, Holakouie Naieni K, Mohammad K, Majdzadeh SR. The World Health Organization quality of Life (WHOQOL-BREF) questionnaire: Translation and validation study of the Iranian version. Journal of School of Public Health and Institute of Public Health Research. 2006; 4(4):1-12. [In Persian]

15. Khaje-Bishak Y, Payahoo L, Pourghasem B, Jafarabadi MA. Assessing the quality of life in elderly people and related factors in tabriz, iran. Journal of caring sciences. 2014; 3(4):257.

16. Ahmadi F, Salar A, Faghihzadeh S. Assessing quality of life among elderly people in Zahedan. Hayat. 2004; 10(22):61-7. [In Persian]

17. Ahangari M, Kamali M, Arjmand Hesabi M. Quality of elderly's life in Tehran senile culture house clubs. Iranian Journal of Ageing. 2007; 2(1):182-9. [In Persian]

18. Farzianpour F, Arab M, Hosseini SM, Pirozi B, Hosseini S. Evaluation of quality of life of the elderly population covered by healthcare centers of marivan and the influencing demographic and 
Journal of Clinical and Basic Research (JCBR). 2019; 3(3): P 25-32.

background factors in 2010. Iranian Red Crescent Medical Journal. 2012; 14(11):695. [DOI:10.5812/ircmj.1834]

19. Zhou J, Hearst N. Health-related quality of life of among elders in rural China: the effect of widowhood. Quality of Life Research. 2016; 25(12):3087-95. [DOI:10.1007/s11136-016-1338y]

20. Onrust S, Cuijpers P. Mood and anxiety disorders in widowhood: a systematic review. Aging \& mental health. 2006; 10(4):327-34. [DOI:10.1080/13607860600638529]

21. Adib Hajbaghery M. Evaluation of old-age disability and related factors among an Iranian elderly population. EMHJ-Eastern Mediterranean Health Journal, 17 (9), 671-678, 2011. 2011 [DOI:10.26719/2011.17.9.671]

22. Milanović Z, Pantelić S, Trajković N, Sporiš G, Kostić R, James N. Age-related decrease in physical activity and functional fitness among elderly men and women. Clinical interventions in aging. 2013; 8:549. [DOI:10.2147/CIA.S44112] 23. Worach-Kardas H, Kostrzewski S. Quality of Life and Health State of Long-Term Unemployed in Older Production Age. Applied research in quality of life. 2014; 9(2):335-53. [DOI:10.1007/s11482-013-9240-z]

24. Campos ACV, e Ferreira EF, Vargas AMD, Albala C. Aging, Gender and Quality of Life (AGEQOL) study: factors associated with good quality of life in older Brazilian communitydwelling adults. Health and quality of life outcomes. 2014; $12(1): 166$. [DOI:10.1186/s12955-014-0166-4] 